\title{
Supplementing Holstein Cows with Low Doses of Bovine Somatotropin Prepartum and Postpartum Reduces Calving-Related Diseases ${ }^{1}$
}

\author{
M. S. Gulay, ${ }^{*}$ M. Liboni, $†$ M. J. Hayen, $\neq$ and H. H. Head ${ }^{2}$ \\ *Department of Physiology, Veterinary Faculty, Mehmet Akif Ersoy University, Burdur, Turkey 15100 \\ †Vallee S.A., Avenue Eng., Luis Berrini, 2nd Floor, Säo Paulo, Säo Paulo, Brazil \\ ¥Department of Animal Sciences, University of Florida, Gainesville 32611-0910
}

\begin{abstract}
The objective of this study was to evaluate whether supplementing Holstein cows with bovine somatotropin (bST; $142.8 \mathrm{mg} / 14 \mathrm{~d}$ ), beginning at $21 \mathrm{~d}( \pm 3 \mathrm{~d})$ before expected calving and continuing through $42 \mathrm{~d}$ in milk $( \pm 3 \mathrm{~d})$, affected the incidence rates of retained fetal membranes (RFM), metritis (MET), clinical mastitis (MAS), digestive problems (DIG), ketosis (KET), milk fever (MF), displaced abomasum (DA, left or right), lameness (LAM), or number of sick cows during the first $60 \mathrm{~d}$ in milk. Data for multiparous Holstein cows from 3 separate trials were merged for analyses $(\mathrm{n}=$ 437). Cows in the bST-supplemented group $(\mathrm{n}=162)$ received biweekly subcutaneous injections of Posilac, whereas control cows $(n=166)$ and a group of cohorts $(\mathrm{n}=109)$ were not supplemented. Incidences of disease were collected from the herd health records. Across all treatment groups, the incidence rates (number of diseased cows divided by the total number of cows) for RFM, MET, MAS, DIG, KET, MF, DA, and LAM were 8.47, 18.31, 16.02, 4.35, 4.35, 3.66, 3.20, and 3.66\%, respectively. The incidence rates of RFM, MET, MAS, DIG, KET, MF, DA, and LAM for cows in the bSTsupplemented, control, and cohort groups were 6.79, 7.83 , and $11.93 \% ; 16.05,7.47$, and $22.94 \% ; 10.49,18.07$, and $21.10 \% ; 1.23,5.42$, and $7.34 \% ; 1.23,6.02$, and $6.42 \% ; 2.47,4.22$, and $4.59 \% ; 2.47,3.61$, and $3.67 \%$; and $3.70,3.61$, and $3.67 \%$, respectively. The percentages of sick cows (number of cows having one or more cases of disease divided by the total number of cows) in the bST-supplemented, control, and cohort groups were $33.95,43.37$, and $49.54 \%$, respectively. Significant chisquared values were detected between the bST-supplemented and control groups for MAS, DIG, and KET, with a greater number of healthy cows in the bST-
\end{abstract}

Received March 19, 2007.

Accepted August 31, 2007.

${ }^{1}$ This manuscript is published as a journal series of the University of Florida Agricultural Experiment Station.

${ }^{2}$ Corresponding author: head@animal.ufl.edu supplemented group. No differences in incidences of diseases or sick cows were detected between the control and cohort groups. Results indicated that a low dose of bST supplemented to Holstein cows for 3 wk prepartum through $60 \mathrm{~d}$ in milk reduced the incidences of some calving-related diseases compared with nonsupplemented controls or cohorts. Importantly, no negative effects of bST supplementation on postpartum calving diseases were detected compared with nonsupplemented cows.

Key words: bovine somatotropin, calving-related disease, Holstein cow, transition period

\section{INTRODUCTION}

The transition from gestation to lactation is a critical phase during each productive cycle of the high-producing dairy cow. Physiological changes that occur during this transition have a great influence on the health and performance of the cow during the subsequent lactation (Drackley, 1999). One important change is the substantial decrease in DMI during the final week of gestation ( $\sim 30 \%$ or greater; Bertics et al., 1992; Drackley, 1999). This decrease in nutrient intake is associated with changes in metabolic and hormonal status (Drackley 1999; Drackley and Dann, 2005). The changes triggered by reduced DMI result in increased mobilization of adipose tissue lipids and decreased availabilities of VFA, glucose, and AA.

During early lactation, a slower increase in DMI relative to the increase in milk production results in a negative energy balance (NEB). The NEB is associated with an increase in hepatic gluconeogenesis, a decrease in the tissue utilization of glucose and in the tissue response to insulin, an increase in the mobilization of fatty acids and protein, and an increase in the utilization of NEFA and BHBA (Bell, 1995) compared with when cows are in a positive energy balance. In addition to these dramatic physiological changes, the postpartum phase of the transition into lactation is also the most critical time for the occurrence of various infectious and metabolic diseases in dairy cows (Grohn et 
al., 1989); their onset is directly and indirectly associated with the physiological changes that occur. Among the diseases directly associated with these physiological changes are fatty liver, ketosis (KET), and hypocalcemia (milk fever, MF) and those indirectly associated include clinical mastitis (MAS), metritis (MET), displaced abomasum (DA, left or right), and digestive disorders (DIG; Ingvartsen, 2006; Mulligan et al., 2006).

Among the strategies that have been used to minimize incidences of metabolic and infectious diseases are better nutritional management and better cow-grouping strategies. Supplementing cows with low doses of bST during the periparturient period also has been evaluated for possible beneficial effects on improving the physiological adaptations and liver function around the time of calving (Gulay et al., 2003, 2004a,b; Liboni et al., 2004). Thus, these studies have directly or indirectly evaluated the efficacy of bST to reduce or prevent the occurrence of some of the diseases mentioned. Somatotropin (ST) orchestrates many physiological processes that may benefit the transition dairy cow. It has direct effects on the partitioning of nutrients to target tissues (Bauman, 1992; Bauman and Vernon, 1993), as well as indirect effects expressed in the mammary gland and other tissues that are mediated by IGF-I (Jones and Clemmons, 1995). It also may have the potential to reduce or even prevent mastitis in ruminants, as indicated by the reduction in SCC (Gulay et al., 2004b) and apparently quicker recovery from mastitis (Burvenich et al., 1999). Moreover, ST may protect the blood-milk barrier and restore the integrity of mammary epithelial tight junctions of an inflamed mammary gland (Burvenich et al., 1999).

Previous studies have suggested that low prepartum or postpartum doses (Stanisiewski et al., 1992; GarciaGavidia et al., 2000; Gulay et al., 2004a) or a higher prepartum dose of bST (Putnam et al., 1999) have had positive effects on milk production responses. In part, the positive response during the ensuing lactation may have been a consequence of improved health status of the bST-supplemented cows. Therefore, the objective of this study was to evaluate whether supplementing Holstein cows with bST (142.8 mg/14 d), beginning at $21 \mathrm{~d}( \pm 3 \mathrm{~d})$ before expected calving date $(\mathbf{E C D})$ and continuing through $42( \pm 3 \mathrm{~d})$ DIM, would affect the incidence rates of retained fetal membranes (RFM), MET, MAS, DIG, KET, MF, DA, or lameness (LAM) during the first 60 DIM.

\section{MATERIALS AND METHODS}

\section{Animals}

Disease incidences observed for multiparous Holstein cows assigned to 3 separate experiments conducted in the University of Florida Dairy Research herd were used. For the first, second, and third experiments, the cows calved between October 1998 and March 2000 (bST $=95$ and control = 98), September 2000 and June 2001 (bST = 42 and control = 42), and August 2001 and August $2002(\mathrm{bST}=25$ and control $=26)$, respectively. All cows were assigned randomly to their respective experiments approximately $4 \mathrm{wk}$ before ECD. The ages of cows at the time they were assigned ranged from 3 to $8 \mathrm{yr}$. Body condition scores $(1=$ thin to $5=$ fat; Ferguson et al., 1994) and BW were recorded $30 \mathrm{~d}$ before ECD and then weekly on the same day each week through $28 \mathrm{~d}$ postpartum. Thereafter, BCS and BW were determined biweekly. Prepartum and postpartum blood samples were collected from the coccygeal vein 3 times weekly. In addition to the 328 experimental cows (bST, $\mathrm{n}=162$; control, $\mathrm{n}=166$ ), data collected retrospectively for an additional group of multiparous herd cows were included in the analysis (cohorts, $\mathrm{n}=109 ; 55,29$, and 25 cows during the first, second, and third experiment). The cohorts were selected randomly from all cows that calved during the same time periods as the experimental cows. These cows were fed the same rations and were managed with the herd after calving, but no other procedures specifically described for the 3 experiments, such as BW and BCS measures or blood sampling, were conducted. Thus, data accumulated on disease incidences for a total of 437 cows were used to evaluate the effects of bST supplementation on cow health performance.

\section{bST Supplementation}

A sterile, prolonged-release, injectable formulation of recombinant DNA-derived bST analog (Posilac, Monsanto, St. Louis, MO) was used. Injections of bST (142.8 $\mathrm{mg})$ at 2 -wk intervals began approximately $21 \mathrm{~d}( \pm 3 \mathrm{~d})$ before ECD, whereas control cows were not injected with bST or an excipient. Regardless of the time of the last injection before calving, the first postpartum injection was within $24 \mathrm{~h}$ of calving, and thereafter injections were at 2 -wk intervals. The last injection was at $42 \pm 3 \mathrm{~d}$ postpartum. All bST injections were subcutaneous in the postscapular region or in the left or right ischiorectal fossa and were administered before the a.m. feeding or milking.

\section{Feeding}

All cows were fed and managed in a calving lot during the prepartum period and in a free-stall barn during lactation. All prepartum cows were fed once daily (1000 to $1200 \mathrm{~h}$ ) for ad libitum consumption of the close-up 
Table 1. Compositions of close-up dry (CUD) ration and TMR fed to Holstein cows during the experiments ${ }^{1}$

\begin{tabular}{|c|c|c|c|c|c|c|}
\hline \multirow{2}{*}{$\begin{array}{l}\text { Composition, }{ }^{2} \\
\%\end{array}$} & \multicolumn{2}{|c|}{ Experiment 1} & \multicolumn{2}{|c|}{ Experiment 2} & \multicolumn{2}{|c|}{ Experiment 3} \\
\hline & CUD & TMR & CUD & TMR & CUD & TMR \\
\hline & & & & & & 56.6 \\
\hline & .28 & 17.67 & 4.87 & 17.18 & 3.80 & 17.4 \\
\hline $\mathrm{ADF}$ & 4 & 25.33 & 23.93 & 22.58 & 24. & 22.3 \\
\hline NDF & 37.34 & 37.16 & 37.29 & 34.66 & 37.42 & 34.74 \\
\hline $\mathrm{NE}_{\mathrm{L}}, \mathrm{Mcal} / \mathrm{kg}$ & 1.58 & 1.68 & 1.54 & 1.56 & 1.47 & 1.60 \\
\hline
\end{tabular}

${ }^{1}$ Diets were formulated with corn silage, cottonseed hulls, citrus pulp, processed soybean meal, cornmeal, soybean meal, whole cottonseeds, and a mineral mixture as part of the concentrate based on analyses of components from the Northeast DHIA Forage Laboratory, Ithaca, NY.

${ }^{2} \mathrm{DM}$ basis.

dry diet (Table 1). Twice daily ( 0800 to $1000 \mathrm{~h}$ and 1300 to $1500 \mathrm{~h}$ ), the postpartum cows were fed a TMR that was formulated with corn silage, cottonseed hulls, citrus pulp, processed soybean meal, cornmeal, soybean meal, whole cottonseeds, and a mineral mixture as part of the concentrate, that allowed 5 to $10 \%$ daily feed refusals (Table 1). Water was available for free-choice consumption.

\section{Data Collection}

All cows were observed daily during the first $60 \mathrm{~d}$ postpartum. Incidences of the specific diseases were recorded on the day of diagnosis and placed in the herd health records (0 to 60 DIM). From these records, the incidence rates (number of diseased cows divided by the total number of cows in each group) were reported for all 3 groups. The diseases presented in this study were the same as those listed by Kelton et al. (1998), which were described as diseases of economic importance to the dairy industry.

\section{Statistical Analyses and Data Evaluation}

To evaluate the effects of treatment, all data collected were analyzed by using the GLM, FREQ, and LOGISTIC procedures of SAS (SAS Institute, 2007). The GLM model included treatment, experiment, and the 2-way interaction of treatment $\times$ experiment. Incidence of RFM, MET, MAS, DIG, KET, MF, DA, LAM, and SICK were analyzed as categorical data by using the FREQ procedure to obtain chi-squared values. The LOGISTIC procedure was used to obtain odds ratios and their respective confidence intervals. Data for cows in the bSTsupplemented group were compared with those of the control and cohort groups individually and also when data for the latter groups were combined into a single group. Significance was declared at $P \leq 0.05$.
Table 2. Disease incidence of multiparous Holstein cows supplemented or not supplemented with bST

\begin{tabular}{|c|c|c|c|c|}
\hline \multirow[b]{2}{*}{ Disease $^{1}$} & \multicolumn{4}{|c|}{ Incidence $^{2}$} \\
\hline & $\begin{array}{c}\mathrm{bST} \\
\mathrm{n}=162\end{array}$ & $\begin{array}{l}\text { Control, } \\
\mathrm{n}=166\end{array}$ & $\begin{array}{l}\text { Cohort, } \\
\mathrm{n}=109\end{array}$ & $P<$ \\
\hline $\mathrm{RFM}, \mathrm{n}^{3}(\%)^{4}$ & $11(6.79)$ & $13(7.83)$ & $13(11.93)$ & NS \\
\hline MET, n (\%) & $26(16.05)$ & $29(17.47)$ & $25(22.94)$ & NS \\
\hline MAS, n (\%) & $17(10.49)$ & $30(18.07)$ & $23(21.10)$ & 0.04 \\
\hline DIG, n (\%) & $2(1.23)$ & $9(5.42)$ & $8(7.34)$ & 0.04 \\
\hline KET, n (\%) & $2(1.23)$ & $10(6.02)$ & $7(6.42)$ & 0.05 \\
\hline MF, n (\%) & $4(2.47)$ & $7(4.22)$ & $5(4.59)$ & NS \\
\hline DA, n (\%) & $4(2.47)$ & $6(3.61)$ & $4 \quad(3.67)$ & NS \\
\hline LAM, n (\%) & $6(3.70)$ & $6(3.61)$ & $4(3.67)$ & NS \\
\hline SICK, n (\%) & $55(33.95)$ & $72(43.37)$ & $54(49.54)$ & 0.03 \\
\hline
\end{tabular}

${ }^{1}$ Retained fetal membranes (RFM), metritis (MET), mastitis (MAS), digestive problems (DIG), ketosis (KET), milk fever (MF), displaced abomasum (DA, left or right), lameness (LAM), and total number of sick animals in a group (SICK).

${ }^{2}$ Number of cows with a new case of a disease during the first 60 DIM. The incidence rate $=$ number of diseased cows divided by the total number of cows in the group.

${ }^{3}$ Number of cases.

${ }^{4}$ Percentage of cows in a group showing cases.

\section{RESULTS}

Of the total 437 cows, 181 cows had one or more incidences of the diseases (41.4\%) evaluated in this study. The diseases with the greatest incidences were MET (18.31\%), MAS (16.02\%), and RFM (8.47\%; Table 2). A total of 106 cows had only one incidence of a health problem $(24.25 \%)$, whereas $60(13.72 \%)$ and $15(3.43 \%)$ cows had 2 and 3 different health problems, respectively. No cow had more than 3 incidences of health problems during the first 60 DIM. A total of 271 incidences were recorded in the current study.

The initial statistical analysis of health data showed that the percentages of SICK cows in the bST-supplemented, control, and cohort groups during the first 60 DIM were $33.95,43.37$, and $49.54 \%$, respectively $(P<$ 0.03; Table 2). Fewer bST-supplemented cows showed 2 or 3 incidences of diseases compared with cows in the combined control and cohort group (27.3 vs. $47.6 \%$ ). Only $3.6 \%$ of bST-supplemented cows had 3 incidences of disease compared with 8.3 and $13.0 \%$ for the control and cohort groups. The categorical and logistic regression analyses indicated that cows in the control group were 1.49 times more likely to have health problems than the bST-supplemented cows (Table 3). Overall, incidence rates of RFM, MET, MF, DA, and LAM did not differ among the treatment groups $(P>0.1)$. However, significant chi-squared values were detected between the bST-supplemented and control groups for MAS ( $P$ $<0.05)$, DIG $(P<0.04)$, and $\operatorname{KET}(P<0.02)$. The categorical and logistic regression analyses showed that cows in the control group were 1.88 times more likely to 
Table 3. Summary of logistic regression analyses of the associations between treatment and diseases during the first 60 DIM

\begin{tabular}{|c|c|c|c|}
\hline \multicolumn{2}{|c|}{ Model } & \multirow{2}{*}{$\begin{array}{l}\text { Odds } \\
\text { ratio }\end{array}$} & \multirow{2}{*}{$\begin{array}{c}\text { Coefficient, } \\
95 \% \mathrm{CI}^{2}\end{array}$} \\
\hline Dependent $^{1}$ & Independent & & \\
\hline \multirow[t]{3}{*}{ MAS } & bST vs. control & 1.881 & $1.003-3.631$ \\
\hline & Cohort vs. control & 0.825 & $0.451-1.524$ \\
\hline & bST vs. uninjected ${ }^{3}$ & 2.036 & $1.156-3.750$ \\
\hline \multirow[t]{3}{*}{ DIG } & bST vs. control & 4.586 & $1.159-30.390$ \\
\hline & Cohort vs. control & 0.724 & $0.268-1.986$ \\
\hline & bST vs. uninjected & 5.271 & $1.485-33.516$ \\
\hline \multirow[t]{3}{*}{ KET } & bST vs. control & 5.128 & $1.325-33.708$ \\
\hline & Cohort vs. control & 0.934 & $0.348-2.646$ \\
\hline & bST vs. uninjected & 5.271 & $1.485-33.516$ \\
\hline \multirow[t]{3}{*}{ SICK } & bST vs. control & 1.490 & $0.954-2.336$ \\
\hline & Cohort vs. control & 0.780 & $0.480-1.267$ \\
\hline & bST vs. uninjected & 1.645 & $1.103-2.470$ \\
\hline
\end{tabular}

${ }^{1}$ Clinical mastitis (MAS), digestive problems (DIG), ketosis (KET), and total number of sick animals in a group (SICK).

${ }^{2} 95 \%$ confidence interval for the odds ratio.

${ }^{3}$ Uninjected $=$ control + cohorts $; \mathrm{n}=275$.

have MAS than the bST-supplemented cows (Table 3). Moreover, cows in the control group were 4.59 and 5.13 times more likely to have DIG and KET than the bSTsupplemented cows.

Differences between the control and cohort groups also were analyzed. Incidence rates of RFM $(P<0.26)$, MET $(P<0.25)$, MAS $(P<0.53)$, DIG $(P<0.52)$, KET $(P<0.89)$, MF $(P<0.88)$, DA $(P<0.98)$, LAM $(P<$ $0.98)$, or SICK $(P<0.32)$ did not differ between the nonsupplemented treatment groups. As a result, data for the bST-supplemented group were compared with that of the combined nonsupplemented groups of cows (control + cohorts, $\mathrm{n}=275$ ). Incidence rates of MAS, DIG, KET, and SICK $(P<0.02)$ differed between the bST-supplemented and nonsupplemented cows. The categorical and logistic regression analyses indicated that cows in the nonsupplemented groups were 1.65 times more likely to have health problems than the bST-supplemented cows.

The effect of the experiment also was evaluated, and no effect was detected for RFM, KET, MF, DA, or LAM $(P>0.1)$. However, there was a significant effect of experiment on MET, MAS, and DIG $(P<0.05)$. Moreover, the percentage of SICK cows during the third experiment (August 2001 to August 2002) was greater than during the first 2 experiments ( 67.57 vs. 38.79 and $34.82 \% ; P<0.05)$. However, no treatment $\times$ experiment interaction was detected for any of the diseases evaluated.

\section{DISCUSSION}

In the current study, bST supplementation from 3 wk prepartum through 60 DIM resulted in improved health status over this time period compared with nonsupplemented controls and cohorts. Of the 8 diseases evaluated (RFM, MET, MAS, MF, DIG, KET, DA, and LAM), the incidences of KET, DIG, and MAS were reduced, but the other 5 diseases had similar incidence rates across groups (Table 2). Importantly, the overall percentage of SICK cows was reduced by about onequarter (34.0 vs. $45.8 \%)$. The transition period ( $3 \mathrm{wk}$ prepartum to $3 \mathrm{wk}$ postpartum) is well-documented as being the most critical time in the productive cycle of the dairy cow. Cows undergo dramatic physiological changes during this time period that often affect their health, subsequent performance, and even their longevity in the dairy herd (Drackley, 1999). Among the changes that occur during this time period are reduced DMI prepartum, inadequate DMI, and greater NEB postpartum, as well as altered circulating concentrations of specific hormones and metabolites, and altered functions of the liver and mammary gland (Bell, 1995; Drackley, 1999; Drackley and Dann, 2005). It has been speculated that bST supplemented during this time period and into early lactation could act as a prophylactic agent and improve the immunocompetence of the cows (Eppard et al., 1996; Gulay et al., 2004b). If factual, these changes should reduce subsequent incidences of diseases and acute health problems typically associated with this time period and better support the rapid rise and overall increase in milk production (Gulay et al., 2004b).

The impact of the occurrence of single or multiple diseases evaluated in this study is substantial because of adverse effects on subsequent health and the associated costs of treatment and reduced milk production. Indeed, cows that manifest one of the diseases are more likely than nonaffected cows to have a greater incidence of one or more of the other diseases (Grohn et al., 1989; Mulligan et al., 2006), thus magnifying the extent of their impact. In fact, epidemiological data show that about one-half of all cows are affected by one or more of these diseases as they pass through the transition period (Drackley, 1999). The overall disease incidence in the current study was less than 50\% (41.8\%), largely because of reduced incidences of diseases in the bSTsupplemented group, which was only $33.95 \%$. Furthermore, there were fewer incidences of multiple diseases in the bST-supplemented group compared with cows in the combined control and cohort group. Importantly, incidences of 3 or more diseases also were reduced in the bST-supplemented cows compared with the control and cohort groups. Thus, there was evidence of positive effects of bST supplementation in reducing the occurrences of both single and multiple diseases during the first 60 DIM. 
Incidences of KET, DA, and DIG negatively affect DMI during early lactation. Cows exhibiting KET during early lactation show a decrease in DMI and reduced depth of the rumen mat, and this leads to an increase in the incidence of DA and DIG (Breukink, 1977; Van Winden and Kuiper, 2003). Digestive problems usually are associated with fermentative dysfunctions, such as when there is a sudden increase in the ingestion of feeds high in concentrates into the nonadapted rumen (Garry, 1996). Ketosis is associated with NEB and intense milk production (Littledike et al., 1981), which leads to an increase in lipid mobilization and synthesis of ketone bodies (Grummer et al., 2004). In addition, because of excessive lipid mobilization, the ability of the liver to export fatty acids as lipoprotein is exceeded. Increased lipid mobilization, coupled with reduced DMI, also adversely affects glucose availability and metabolism because of a net shortage of propionate, AA, and glycerol to support gluconeogenesis. Thus, insufficient glucose would be available to provide the energy required for lactose and milk synthesis. Although specific causes of the reduced incidences of KET and DIG could not be determined in the current study, the findings would be consistent with improved DMI during the transition period through 60 DIM.

Although no direct measure of DMI was made in all the experiments that provided data for the evaluation of cow health, indirect evidence suggests that prepartum and postpartum DMI likely were improved in bSTsupplemented cows. For example, bST-supplemented cows were better able to maintain BW and BCS following calving than nonsupplemented cows (Gulay et al., 2003). Furthermore, they showed better recovery of BCS during early lactation, even though they produced more milk. Although not measured, we speculate that the bST-supplemented cows had greater DMI during the transition period. This would have enabled them to adapt better to dietary changes after calving and maintenance of the microbial population in the rumen (Goff and Horst, 1997). Gulay et al. (2004b) also suggested that the efficiency of milk production was improved by bST supplementation. Therefore, it is likely that improvements were expressed in metabolism and in the mobilization of lipids and protein from body tissues to provide nutrients to support rapidly increasing milk production, with no observed adverse effects on health. Other interpretations are possible, but overall, the health results underscore that there were beneficial effects of low doses of bST supplementation around calving and during early lactation.

Somatotropin is considered the primary homeorhetic regulator during pregnancy and lactation (Bauman and Vernon, 1993). Actions of ST associated with increased milk production and the health of dairy cows include direct and indirect coordination of activities of various tissues and organs and the partitioning of carbohydrates, lipids, proteins, and minerals to specific tissues and organs (Bauman, 1992). During lactation, ST (or supplemental bST) partitions ingested nutrients and those mobilized from the liver and body tissues preferentially to the mammary gland to provide the needed energy to offset the deficit and to enhance milk synthesis. Multiple changes in liver and mammary gland functions, metabolism, and blood flow are provoked by increased plasma concentrations or ratios of ST, insulin, IGF-I, and triiodothyronine before or after parturition. Indeed, previous research showed that supplementing cows with bST during the postpartum period stimulates glucose and lipid metabolism, and typical responses included decreased whole-body oxidation of glucose (Cohick et al., 1989), increased hepatic rates of gluconeogenesis (Bauman et al., 1988), decreased glucose response to insulin, and better utilization of NEFA (Bauman and Vernon, 1993). Overall, the complex array of actions provoked by bST are beneficial to DMI, utilization of ingested and mobilized nutrients, the health of the cows, and subsequent milk production (Drackley, 1999; Garcia-Gavidia et al., 2000; Gulay et al., 2004a). Thus, it seems likely that the similar partitioning effects exerted are commensurate with the lower dose supplemented during the transition period and early lactation. The actions of bST supplementation observed in the current study are consistent with the role of ST (or supplemented bST) as the primary homeorhetic regulator during lactation.

In the current study, evidence of a possible prophylactic effect or enhanced immunocompetence because of bST supplementation also was suggested by the reduced incidence of MAS during the first 60 DIM. Although a slight increase in MAS in lactating cows supplemented with a full dose of bST $(500 \mathrm{mg} / 14 \mathrm{~d})$ was reported, it was associated primarily with the increased milk yield of the supplemented cows (White et al., 1994). Milk production was increased with lower doses of bST, albeit less than when the full dose was supplemented, but reduced levels of SCC were observed compared with those in nonsupplemented cows (Gulay et al., 2004b). In previous research, supplementation of lactating cows with bST increased absolute leukocyte counts in the blood (Elvinger et al., 1991). Moreover, Burvenich et al. (1999) suggested that ST could enhance the function of neutrophils, protect the blood-milk barrier, and restore the integrity of the tight junctions in the mammary epithelium of an inflamed mammary gland. Therefore, the same positive effects of higher peripheral concentrations of ST (Gulay et al., 2003, 2004b; Liboni, 2004) on MAS likely would be true under healthy conditions (Burvenich et al., 1999). This may have occurred 
because of positive effects of ST and IGF-I on the cytoskeleton, tubular mRNA, and cytoskeletal organization, as observed in rats (Berfield et al., 1997; Goh et al., 1997). Whatever the cause, in the current study bST-supplemented cows had fewer incidences of MAS. This decrease, coupled with beneficial homeorhetic actions of bST, doubtless contributed to greater milk production of the supplemented cows.

Results of this study indicated that supplementation of cows with low doses of bST during the prepartum and early postpartum periods resulted in reduced incidences of a number of the metabolic and infectious diseases that most often occur during the periparturient period and early lactation. Specifically, bST supplementation reduced new cases of DIG, KET, and MAS. Importantly, in no case was the incidence rate of any of the 8 diseases evaluated greater in the bST-supplemented group of cows than in the nonsupplemented groups. Thus, results of this retrospective epidemiological study carried out by using data collected over the course of several years showed that cows supplemented with bST were less likely to have calving-related disorders than were their nonsupplemented contemporaries.

\section{ACKNOWLEDGMENTS}

The authors thank the staff at the Dairy Research Unit of the University of Florida for their assistance with cow management, especially Mary E. Russell, and also the veterinary practitioners for their expertise in health care practices. Partial financial support for this project was provided through the dairy check-off program.

\section{REFERENCES}

Bauman, D. E. 1992. Bovine somatotropin: Review of an emerging animal technology. J. Dairy Sci. 75:3432-3451.

Bauman, D. E., C. J. Peel, W. D. Steinhour, P. J. Reynolds, H. F. Tyrrell, A. C. G. Brown, and G. L. Haaland. 1988. Effect of bovine somatotropin on metabolism of lactating dairy cows: Influence on rates of irreversible loss and oxidation of glucose and nonesterified fatty acids. J. Nutr. 118:1031-1040.

Bauman, D. E., and R. G. Vernon. 1993. Effects of exogenous bovine somatotropin on lactation. Annu. Rev. Nutr. 13:437-461.

Bell, A. W. 1995. Regulation of organic nutrient metabolism during transition from late pregnancy to early lactation. J. Anim. Sci. 73:2804-2819.

Berfield, A. K., D. Spicer, and C. K. Abrass. 1997. Insulin-like growth factor I (IGF-I) induces unique effects in the cytoskeleton of cultured rat glomerular mesangial cells. J. Histochem. Cytochem. 45:583-593.

Bertics, S. J., R. R. Grummer, C. Cadornigavalino, and E. E. Stoddard. 1992. Effect of prepartum dry matter intake on liver triglyceride concentration and early lactation. J. Dairy Sci. 75:1914-1922.

Breukink, H. J. 1977. Etiology and pathogenesis of abomasal displacement. Tijdschr. Diergeneesk. 102:611-618.

Burvenich, C., M. J. Paape, D. Hoeben, H. Dosogne, A. M. MassartLeen, and J. Blum. 1999. Modulation of the inflammatory reaction and neutrophil defense of the bovine lactating mammary gland by growth hormone. Domest. Anim. Endocrinol. 17:149-159.
Cohick, W. S., K. Plaut, S. C. Sechen, and D. E. Bauman. 1989. Temporal pattern of IGF-I response to exogenous GH in lactating cows. Domest. Anim. Endocrinol. 6:263-274.

Drackley, J. K. 1999. Biology of dairy cows during the transition period: The final frontier? J. Dairy Sci. 82:2259-2273.

Drackley, J. K., and H. M. Dann. 2005. New concepts in nutritional management of dry cows. Adv. Dairy Technol. 17:11-23.

Elvinger, F., P. J. Hansen, and R. P. Natzke. 1991. Modulation of function of bovine polymorphonuclear leukocytes and lymphocytes by high temperature in vivo and in vitro. Am. J. Vet. Res. 52:1692-1698.

Eppard, P. J., J. J. Veenhuizen, W. J. Cole, P. G. ComensKeller, G. F. Hartnell, R. L. Hintz, L. Munyakazi, P. K. Olsson, R. H. Sorbet, T. C. White, C. A. Baile, R. J. Collier, J. P. Goff, and R. L. Horst. 1996. Effect of bovine somatotropin administered to periparturient dairy cows on the incidence of metabolic disease. J. Dairy Sci. 79:2170-2181.

Ferguson, J. D., D. T. Galligan, and N. Thomsen. 1994. Principal descriptors of body condition score in Holstein cows. J. Dairy Sci. 77:2695-2703.

Garcia-Gavidia, A., M. S. Gulay, M. J. Hayen, C. J. Wilcox, T. I. Belloso, and H. H. Head. 2000. Responses of Holstein cows to prepartum and postpartum injections of bovine somatotropin (bST). J. Dairy Sci. 83:220.

Garry, F. B. 1996. Indigestion in ruminants. Pages 824-858 in Large Animal Internal Medicine: Diseases of Horses, Cattle, Sheep, and Goats. B. P. Smith, ed. Mosby Inc., St. Louis, MO.

Goff, J. P., and R. L. Horst. 1997. Physiological changes at parturition and their relationship to metabolic disorders. J. Dairy Sci. 80:1260-1268.

Goh, E. L. K., T. J. Pircher, T. J. J. Wood, G. Norstedt, R. Graichen, and P. E. Lobie. 1997. Growth hormone-induced reorganization of the actin cytoskeleton is not required for STAT5 (signal transducer and activator of transcription-5)-mediated transcription. Endocrinology 138:3207-3215.

Grohn, Y. T., H. N. Erb, C. E. McCulloch, and H. S. Saloniemi. 1989. Epidemiology of metabolic disorders in dairy cattle: Association among host characteristics, disease and production. J. Dairy Sci. 72:1876-1885.

Grummer, R. R., D. G. Mashek, and A. Hayirli. 2004. Dry matter intake and energy balance in the transition period. Vet. Clin. Food Anim. Pract. 20:447-470.

Gulay, M. S., A. N. Garcia, M. J. Hayen, C. J. Wilcox, and H. H. Head. 2004a. Responses of Holstein cows to different bovine somatotropin (bST) treatments during the transition period and early lactation. Asian-australas. J. Anim. Sci. 17:784-793.

Gulay, M. S., M. J. Hayen, M. Liboni, T. I. Belloso, C. J. Wilcox, and H. H. Head. 2004b. Low doses of bovine somatotropin during the transition period and early lactation improves milk yield, efficiency of production, and other physiological responses of Holstein cows. J. Dairy Sci. 87:948-960.

Gulay, M. S., M. J. Hayen, L. C. Teixeira, C. J. Wilcox, and H. H. Head. 2003. Responses of Holstein cows to a low dose of somatotropin (bST) prepartum and postpartum. J. Dairy Sci. 86:31953205.

Ingvartsen, K. L. 2006. Feeding- and management-related diseases in the transition cow: Physiological adaptations around calving and strategies to reduce feeding-related diseases. Anim. Feed Sci. Technol. 126:175-213.

Jones, J. I., and D. R. Clemmons. 1995. Insulin-like growth factors and their binding proteins: Biological actions. Endocr. Rev. 16:3-34.

Kelton, D. F., K. D. Lissemore, and R. E. Martin. 1998. Recommendations for recording and calculating the incidence of selected clinical diseases of dairy cattle. J. Dairy Sci. 81:2502-2509.

Liboni, M. 2004. Bovine somatotropin supplementation during the transition period and early lactation as a management strategy to improve physiological adaptations, liver function, health and productivity of dairy cows. PhD Diss. University of Florida, Gainesville.

Liboni, M., M. J. Hayen, M. S. Gulay, L. Badinga, T. I. Belloso, and H. H. Head. 2004. Influence of low doses of bovine somatotropin (bST) on plasma NEFA and $\beta$-hydroxybutyrate, hepatic lipid me- 
tabolism, and gene expression of Holstein transition cows. J. Dairy Sci. 87:194.

Littledike, E. T., J. W. Young, and D. C. Beitz. 1981. Common metabolic diseases of cattle: Ketosis, milk fever, grass tetany, and downer cow complex. J. Dairy Sci. 64:1465-1482.

Mulligan, F. J., L. O'Grady, D. A. Rice, and M. L. Doherty. 2006. A herd health approach to dairy cow nutrition and production diseases of the transition cow. Anim. Reprod. Sci. 96:331-353.

Putnam, D. E., G. A. Varga, and H. M. Dann. 1999. Metabolic and production responses to dietary protein and exogenous somatotropin in late gestation dairy cows. J. Dairy Sci. 82:982-995.

SAS Institute. 2007. SAS OnlineDoc User's Guide, Version 8. SAS Institute, Cary, NC. http://support.sas.com/rnd/app/da/stat.html Accessed Feb. 7, 2007.
Stanisiewski, E. P., L. F. Krabill, and J. W. Lauderdale. 1992. Milk yield, health, and reproduction of dairy cows given somatotropin (Somavubove) beginning early postpartum. J. Dairy Sci. 75:2149-2164.

Van Winden, S. C. L., and R. Kuiper. 2003. Left displacement of the abomasum in dairy cattle: Recent developments in epidemiological and etiological aspects. Vet. Res. 34:47-56.

White, T. C., K. S. Madsen, R. L. Hintz, R. H. Sorbet, R. J. Collier, D. L. Hard, G. F. Hartnell, W. A. Samuels, G. de Kerchove, F. Adriaens, N. Craven, D. E. Bauman, G. Bertrand, Ph. Bruneau, G. O. Gravert, H. H. Head, J. T. Huber, R. C. Lamb, C. Palmer, A. N. Pell, R. Phipps, R. Weller, G. Piva, Y. Rijpkema, J. Skarda, F. Vedeau, and C. Wollny. 1994. Clinical mastitis in cows treated with Sometribove (recombinant bovine somatotropin) and its relationship to milk yield. J. Dairy Sci. 77:2249-2260. 